\title{
Booming Biotechnology: The Promising Future in Healthcare
}

\author{
Sridevi I Puranik ${ }^{1,2}$ and Shridhar C Ghagane ${ }^{2,3 *}$ \\ ${ }^{1}$ Department of Biotechnology, KLES R. L. Science Institute (Autonomous), Belagavi-590001, Karnataka, India. \\ ${ }^{2}$ Department of Biotechnology and Microbiology, Karnatak University, Dharwad-580003, Karnataka, India. \\ ${ }^{3}$ Department of Urology, KLES Kidney Foundation, KLES Dr. Prabhakar Kore Hospital \& MRC, Belagavi-590010, Karnataka, India.
}

Submission: August 20, 2017; Published: August 22, 2017

*Corresponding author: Shridhar C Ghagane, Department of Urology, KLES Kidney Foundation, KLES Dr Prabhakar Kore Hospital \& MRC, Belagavi-590010, Karnataka, India; Tel: +91-9739717296; Email: Shridhar.kleskf@gmail.com

\section{Opinion}

Over the past decades, biotechnology occasionally described as the oldest profession has grown rapidly in the world. It has evolved into a modern technology without which progress in agriculture, pharmaceutical industries and healthcare sector would be scarcely imaginable [1]. Biotechnology dates back to ancient era where evidence from holy books reveals numerous examples on the existence of biotechnology [2]. Namely, it deals with the conversion of grapes to wine, of dough to bread and of milk to cheese. The oldest biotechnological processes are found in microbial fermentations, as born out by the Babylonian tablet dated circa 6000 B.C., explaining the preparation of beer. During Vedic period (5000-7000 B.C.) Aryans had been performing daily Agnihotra or Yajna. In Ayurved, production of 'Asava' and 'Arista' using different substrates and flowers of mahua (Madhuca indica) or dhataki (Wodfordia fructicosa) has been well characterized until today since Vedic period [1]. One of the materials used in Yajna is animal fat (i.e. ghee) which is fermented product of milk.

These elucidation from the prehistoricperiod has now flourish into a modern biotechnology playing crucial role in developing advanced technology that has resulted into newer product like genetically modified organisms, hybrid vegetables, advanced diagnostics kits, pre and pro biotics and many more. These arrays of products have taken the global biotech sector to billion dollars turnover across the globe. Emphasizing on medical sector modern biotechnology plays a crucial role both in the elucidation of the molecular causes of disease and in the development of new diagnostic methods and enhanced targeted drugs [3]. These developments have led to the birth of a new economic sector. The biotech industry associated mostly with small startup companies. For their part, the more established healthcare companies have also been employing these modern techniques, known collectively as biotechnology, successfully for many years. By studying the molecular foundations of ailments, they have established more specific ways of combating diseases than ever before. This new knowledge permits innovative strategies to treatment, with new classes of drugs, biopharmaceuticals confronting earlier unknown targets [4]. Increasing attention is also being paid to modifications among discrete patients, with the result that in the case of many diseases the goal of knowing in advance, whether and how a precise treatment will work in a given patient is now within reach. For some patients this dream has already become reality. Diagnosis and treatment are thus satisfying gradually. When a disease, rather than being diagnosed based on more or less vague signs and symptoms, can be detected based on molecular evidence, the prospect of effective treatment depends mainly on what diagnostic techniques are available. To the healthcare diligence, this signifies a major improvement in that diagnosis and treatment are increasing ever-closer together, with clear benefits for biotechnology and pharmaceutical industries that possess competence in both these areas. To patients, advancement in medical biotechnology means one thing above all: more specific, harmless and more efficient treatment of their disorders $[3,4]$. To the healthcare sectors, it characterizes both an opportunity and a challenge. More than $40 \%$ of the pharmaceutical products are currently accounted by biopharmaceuticals, and this figure is rising [5]. Biotechnology has made many contributions in vaccine, recombinant products, tissue regenerative medicine and many more in progress, these application drives to take up much more advanced technology in healthcare sector, which stands as a promising future.

\section{References}

1. https://raunakms.wordpress.com/the-importance-of-biotechnologyin-todays-time Accessed on 18 August 2017. 
2. Naik G (2017) New York spreads the news with [dollar] 1.15 billion biotech plan 35: 191.

3. Arora P (2005) Healthcare biotechnology firms in India: Evolution, structure and growth. Current Science 89(3): 458-463.

4. Ghagane S, Nerli R, Baligar P, Hiremath M. Status and Application of Recombinant DNA Therapeutic Products Used in Clinical Practices:

This work is licensed under Creative

Commons Attribution 4.0 Licens

DOI: 10.19080/AIBM.2017.05.555668
An Indian Scenario. 2016. Available at SSRN: https://ssrn.com/ abstract $=2783940$..

5. Thorsteinsdóttir H, Quach U, Daar AS, Singer PA (2004) Conclusions: promoting biotechnology innovation in developing countries. Nature Biotechnology 22: DC48-DC52.

\section{Your next submission with Juniper Publishers will reach you the below assets}

- Quality Editorial service

- Swift Peer Review

- Reprints availability

- E-prints Service

- Manuscript Podcast for convenient understanding

- Global attainment for your research

- Manuscript accessibility in different formats

( Pdf, E-pub, Full Text, Audio)

- Unceasing customer service

Track the below URL for one-step submission https://juniperpublishers.com/online-submission.php 